\title{
Cropping Systems Rsearch: Reconsidering Agricultural Experimental Approaches
}

Laurie E. Drinkwater

\begin{abstract}
Summary. Systems approaches to research can be used to study characteristics of agricultural systems that cannot be addressed using conventional factorial experiments. The goal of a factorial experiment is to break down a complex system in order to isolate and study specific components and identify cause-effect relationships. In contrast, systems experiments aim to understand how a complex system functions as a whole and thus requires that intact systems be studied. Two approaches have been successfully applied to agricultural systems research: 1) field station experiments where simulated cropping systems are established in replicated plots and 2) studies of intact agroecosystems using commercial farms as study sites. These two approaches have complementary strengths and limitations and have made significant contributions to our understanding of ecological processes in agricultural systems. The development of sustainable agroecosystems will be best accomplished using an integrated research approach combining systems experiments with appropriately designed factorial experiments.
\end{abstract}

The concept of an agroecosystem evolved through extension of
the ecosystem paradigm, a central organizing principle in ecol
ogy, to agriculture (Lowrance et al., 1984). A system is defined as a group of interrelated elements forming a functional entity that is more than the sum of its parts. Therefore, an ecosystem is an assemblage of organisms and their physical environment that is largely selfregulating and is shaped by species-species and species-environment interactions. An agroecosystem is a managed ecosystem in which crop production is the primary function.

Ecosystems research aims to understand the role of structure (abiotic and biotic components) in determining function (net primary productivity, nutrient and energy flows). Studies of agroecosystems attempt to understand the role of structure and management in determining function. The central underlying assumption of a systems approach is that agroecosystems are complex, and interrelationships among environmental conditions, management, and biological processes are important in determining outcomes such as yield, pest pressure, and environmental impacts. Experiments are often designed to study processes at multiple spatial and temporal scales and usually require the involvement of a multidisciplinary research team (Table 1). Perhaps the most important defining characteristic of agroecosystem studies is that they offer the opportunity to test broad, integrated hypotheses. 
The precise boundaries of an agroecosystem depend on the nature of the questions being addressed. For questions addressing biophysical processes, such as management effects on soil organic matter (SOM) decomposition, an agroecosystem is often defined as a field or experimental plot (Crossley et al., 1984). Cropping systems experiments tend to emphasize a set of practices corresponding to a management system and usually address questions at the field or farmscale (e.g., Liebhardt et al., 1989; Mueller et al., 2002). On the other hand, if one wishes to address questions at larger scales, such as regional nutrient budgets or interactions between management, yields and socioeconomic properties, the boundaries of an agroecosystem may encompass an entire state (David and Gentry, 2000) or may consist of many farms and their markets (Hart, 1984).

This paper provides an overview of agroecosystems research and compares the strengths and weaknesses of reductionist and systems experiments. Different approaches to agro-ecosystems studies are discussed.

\section{Limitations of conventional agricultural research}

Most agricultural research is conducted in reductionist, factorial experiments. A factorial experiment permits the deconstruction of a complex system in order to isolate specific components and identify cause-effect rela- tionships. In a factorial experiment, the effects of one or more factors are investigated at two or more levels simultaneously, usually by comparing all possible combinations (Little and Hills, 1978). All other attributes except for those of interest are held constant. Factorial experiments are excellent for studying isolated components, however, they may not predict the performance of intact agroecosystems. The limitations of a reductionist approach are particularly relevant in agriculture when factorial experiments are conducted in the absence of an ecosystem context. Most field experiments are of brief duration ( 2 to 3 years) and are conducted in small plots on agricultural experiment stations. An underlying, and often unintentional, assumption of experiments conducted in this manner is that ecosystem-level characteristics that change over longer time periods (i.e., $\geq 5$ years) or larger spatial scales do not affect experimental outcomes. However, studies of intact agroecosystems have established the importance of both long-term and landscape scale effects (Letourneau, 1997; Aref and Wander, 1998). These ecosystem-level characteristics constitute the background of all field experiments but are rarely accounted for in agricultural experimental designs. The absence of a larger, systems perspective can lead to incorrect conclusions.

For example, soil management history plays a major role in determining nutrient dynamics. When treatments such as no-tillage are imposed in soils after decades of conventional tillage, changes in carbon $(\mathrm{C})$ and nitrogen $(\mathrm{N})$ cycling processes reduce plant available $\mathrm{N}$ (Meisinger et al., 1985.) This effect declines over time as the system reaches a new steady state. Similarly, shifting from inorganic N fertilizers to organic amendments such as compost or green manures also alters $\mathrm{C}$ and $\mathrm{N}$ cycling (Harris et al., 1994; Wander et al., 1994; Reider et al., 2000). When these treatments are imposed in soils after long-term management with inorganic fertilizer, $\mathrm{N}$ availability can be limiting initially, but then gradually increases as the soil cycling processes reach a new equilibrium (Liebhardt et al., 1989; Clark et al., 1999). Therefore, care must be taken in comparing alternative and conventional soil management practices since the outcomes are governed by soil processes requiring more than one or two growing seasons to reach equilibrium.

Landscape characteristics at spatial scales larger than experiment stations can also impact experimental outcomes. The surrounding landscape plays a significant role in determining insect pest damage, particularly in situations where biological controls are being used (Letoureau, 1997). Landscape heterogeneity influences the abundance and diversity as well as the behavior of pest and beneficial insect communities (Altieri and Todd, 1981; Ryszkowski et al., 1993; Letourneau, 1997). For example, increased insect pest damage under conditions with greater $\mathrm{N}$ availability is observed in greenhouse and small plot experiments

Table 1. Common characteristics of systems experiments in agriculture.

\section{Property}

Realistic, intact agroecosystems are studied

Most systems research is conducted either in simulated farming systems or in actual farms or landscapes. Many characteristics (tillage, rotation, fertility sources, etc.) vary between treatments.

\section{Interdisciplinary}

Broad hypotheses which cross disciplines are often tested so scientists from several disciplines work together. Some of the most informative experiments have included farmers in the research team (Scow et al., 1994; Temple et al., 1994).

\section{Long-term}

Cropping systems studies have shown that differing management regimes cause cropping systems to change over time (Drinkwater et al., 1995; Liebhardt et al., 1989; Peters et al., 1997). Some of these processes appear to take decades and, as a result, short-term experiments can lead to incorrect conclusions.

\section{Multiscale}

Integration across spatial scales and levels within the system, i.e., from micro-scale processes such as nitrogen cycling in the rhizosphere to landscape and watershed scale nitrogen flows. Some agricultural systems studies include biophysical as well as social and economic factors (Reaganold 2001). 
but is usually not detectable in studies of intact agroecosystems (Letourneau, 1997). Marino and Landis (1996) compared the efficacy of parasitoids in fields surrounded by landscapes of varying complexity and found that parasitoid behavior was influenced by the surrounding landscape but not by fieldscale vegetation factors. For pest biocontrol strategies involving natural enemies, particularly those that are highly mobile, the success or failure of these practices could be determined by the composition of the landscape surrounding the agricultural research station. A replicated factorial experiment conducted at a single site may not be adequate for evaluating the efficacy of pest control practices.

A second assumption driving reductionist experimental designs is that it is best to remove all potential sources of variability. As a result, treatments may be oversimplified and a factor that interacts with the cause-effect relationship under study may be modified or eliminated. In a long-term factorial experiment spanning 11 years, Larson et al. (1972) studied the effects of crop residue quality using plots where residues were imported rather than being grown in situ. Corn (Zea mays) was grown every year and then removed and varying amounts of either alfalfa (Medicago sativa) shoots or corn stover were then added back to the plots to determine the importance of residue quantity versus quality on SOM. This design had the advantage of allowing researchers to control the amount of organic residue added to the plots more precisely than if corn and alfalfa were planted in the plots to establish the treatments. Larson et al. (1972) concluded that SOM levels were determined by the amount of organic residues but that residue quality effects were insignificant. Since residue quality is an implicit characteristic of crop species, the results of this experiment have been interpreted to suggest that crop species do not effect SOM levels (e.g., Campbell and Zentner, 1993). However, recent agroecological studies suggest the opposite (Drinkwater et al., 1998; Gregorich et al., 2001). The apparent contradiction can be explained with more recent evidence indicating that roots play a significant role in SOM dynamics (Hayes and Beare, 1997; Puget and Drinkwater, 2001) and that differences between plant species in SOM cycling are due to differences in the fate of root-derived organic matter
(Drinkwater and Puget, 2001). By maintaining a constant background of corn roots, Larson et al. (1972) unintentionally removed a major determinant of plant species effects on SOM levels and reached incorrect conclusions.

Finally, the factorial design dictates that all management practices other than the experimental factors must be the same for all treatments. As a result, the management may not reflect a realistic cropping system since, in some cases, changing a specific management practice requires modification of other components of the management system. This may be a relatively minor issue but it is important to consider as it also contributes to the difficulties of developing components of management systems in isolation from one another.

\section{Cropping systems experiments: an example}

The fundamental features of an experiment design aimed at understanding how agroecosystems function as a whole is perhaps best illustrated by briefly describing a sample cropping systems experiment. The Farming Systems Trial, which is still continuing, was initiated in 1981 and compares three distinct production systems: a conventional cash grain production system and two organically managed cropping systems (Table 2). Treatments are replicated eight times and are arranged in a randomized complete block design (Liebhardt et al., 1989). The primary difference between this and a factorial study is that the suite of specific practices imposed in each treatment represents an intact management strategy. As a result, the treatments differ in many respects including crop rotation, fertility source, and the timing and frequency of tillage (Table 2). Simply changing the $\mathrm{N}$ source from mineral fertilizer to biologically fixed $\mathrm{N}$ from a green manure has several ramifications. To allow time for the green manure to reach maximum biomass, tillage is delayed in the organic system. After incorporation, the green manure requires time to decompose so the planting date for the corn crop following the green manure is often later compared to that in the conventional system in which fertilizer is used. Furthermore, to allow hairy vetch (Vicia villosa) to be grown preceding corn, the rotation includes a winter grain. Consequently, the legumebased cropping system differs from the conventional system in terms of both crop rotation and $\mathrm{N}$ source. Because of this change in rotation other differences in cultural practices between the conventional and legume-based system accrue, including modifications in the timing and frequency of tillage and a reduction in the fallow periods (Table 2). These changes in cultural practices have secondary effects on other components of these agroecosystems such as weed and arthropod populations and thus influence the choice of cultural practices in these areas (Liebman and Dyck, 1993; Letourneau, 1997). As with all experiments, statistical analysis is required to identify differences among treatments. However, specific cause-effect relationships (i.e., whether differences in nitrate leaching rates are due to differences in $\mathrm{N}$ source, crop rotation or timing of tillage; whether differences in yields are due to differences in $\mathrm{N}$ availability or weed competition) cannot be identified without further experimentation. Instead, this experiment has contributed to our understanding of how different cropping system behave in terms of relationships between structure (management practices and biological and environmental attributes) and function (i.e., yields, environmental impacts and long-term sustainabililty) (Harris et al., 1994; Drinkwater et al., 1998; Peterson et al., 1999).

\section{Complementarity of systems and factorial approaches}

The contrasting strengths and limitations of factorial and systems approaches clearly suggest that their complementary application is likely to produce an understanding of agroecosystems better suited to meeting current needs than either approach alone. A number of examples exist in which factorial experiments have been used within a systems context to shed unique insight on agroecosystem function. For example, subplots have been used within a larger experiment to manipulate a single factor and test specific, mechanistic hypotheses in systems studies (Harris et al., 1994; Peters et al., 1992; Puget and Drinkwater, 2001). To give a specific example, I will continue with the Farming Systems Trial described above. This study has demonstrated cropping system effects on SOM composition (Wander et al., 1994), nutrient cycling (Drinkwater et al., 
Table 2. Summary of cultural practices in the Farming Systems Trial at the Rodale Institute (Kutztown, Pa.) where three different agronomic cropping systems are being compared. Each cropping system is replicated eight times and plots are arranged in a randomized, complete block design. (modified from Wander et al., 1994, Peters et al., 1997).

\section{Cultural practice}

Crop rotation

Amount and type of $\mathrm{N}$ input

Annual groundcover condition

Primary tillage and average frequency

Weed control

\author{
Manure-based
}

Corn (Zea mays), soybeans (Glycine max), small grains, hay (legume/grass mix)

$91 \mathrm{~kg} \cdot \mathrm{ha}^{-1} \mathrm{~N}$ per year ${ }^{\mathrm{z}}$ steer manure, leguminous residue

Growing plants: $73 \%$; fallow w/residues: $20 \%$; bare fallow: $7 \%$

Moldboard plow, $0.8 \times$ per year

Rotary hoeing, cultivation, rotation
${ }^{2} 1 \mathrm{~kg} \cdot \mathrm{ha}^{-1}=0.9 \mathrm{lb} /$ acre.

1998), yields and weed dynamics (Liebhardt et al., 1989). Hypotheses about mechanisms causing these differences were also offered but they could only be addressed through use of reductionist approaches. Liebhardt et al. (1989) found reduced corn yields in the two organic systems during the first 4 years and hypothesized that weed competition contributed to reductions in yield. Subplots were established within larger plots to compare yield following complete weed removal by hand to those following production under ambient weed pressure, while all other factors remained constant (Peters et al., 1992). Similar approaches have been used to test mechanistic hypotheses about nutrient cycling processes using stable isotopes or litter bags (Harris et al., 1994; Collins et al., 1999; Daroub et al., 2000; Drinkwater et al., 2000; Puget and Drinkwater, 2001; Krameret al., 2002). Harris et al. (1994) and Kramer et al., (2002) used microplots within cropping systems experiments to study the fate of $\mathrm{N}$ additions originating from the green manure versus those added as mineral fertilizer using ${ }^{15} \mathrm{~N}$ labeled legume residues and fertilizer. Microcosm or pot experiments using soils from systems experiments or commercial farm sites have been used to study soil microbial community function (Lundquist et al., 1999; Fließbach et al., 2000) as well as soil-plant-arthropod (Phelan et al., 1995) and soil community-plant pathogen interactions (Workneh et al., 1994). If the plot size permits, experiments can be nested within the main plots or fields (Mueller et al., 2002).

\section{Statistical analysis of systems studies}

While univariate analysis of variance can be used, multivariate analyses have also proven to be useful in agroecosystems studies. Multivariate analysis can quantify multiple interac- tions simultaneously and identify ecological ramifications not revealed by univariate statistics (Lechowicz and Shaver, 1982). A number of multivariate techniques have proven useful in interpreting the complex data sets generated by systems studies (Stynes and Veitch 1981; 1983; Drinkwater et al., 1995; Clark et al., 1999; Wander and Bollero, 1999). Using principal components analysis and canonical discriminant analysis, Drinkwater et al. (1995) demonstrated that management effects on soil processes could be detected across a range of soil types despite having significant variability in specific farming practices within management groups. Clark et al. (1999) combined principal components analysis with traditional analysis of variance to evaluate the relative importance of yield-limiting factors across four simulated cropping systems in a replicated plot experiment. A useful reference for use of multivariate statistics is Afifi and Clark (1996).

\section{Farm sites versus simulated systems in research plots}

Two distinct approaches have been used to conduct agricultural systems experiments (Shennan et al., 1991). One involves simulating agroecosystems by establishing replicated experiments on a research station while the other relies on commercial production systems or agricultural landscapes as study sites. Choosing an approach depends on the goal of the experiment and the hypotheses to be tested. On-farm systems research will be dealt with in greater detail here as other papers in this volume address simulated cropping systems studies.

StUdies USing Simulated Agroecosystems. There are now a substantial number of replicated, onstation systems experiments comparing various simulated production systems (Liebhardt et al., 1989; Janke et al., 1991; Temple et al., 1994; Posner et al., 1995; Robertson et al., 2000, Cavigelli et al., 2000; Reider et al., 2000; Poudel et al., 2001; Mueller et al., 2002; Delate, 2002). Replicated systems experiments are occasionally established on commercial farms (Reganold et al., 2001). Replicated interdisciplinary cropping systems studies offer a number of advantages by allowing whole management systems to be compared while reducing the influence of confounding variability in soil type, management history, surrounding habitat or microclimate. Another advantage is that promising, innovative cropping systems not currently in use by farmers may be studied. Finally, this approach is particularly useful for detailed investigations of temporal changes that may occur following implementation of new management schemes since all treatments begin with well-defined time zero condition (so-called transition effects after Liebhardt et al., 1989). Viewed from another perspective, these strengths can become disadvantages. Since data are obtained from a single location, the effect of varying environmental conditions (such as soil texture or landscape level biodiversity) on the cropping systems cannot be studied. Also, one or two sets of practices are used to represent a type of production system (e.g. Liebhardt et al., 1989; Temple et al., 1994), whereas in practice, there are usually many variations on a central theme.

On-farm systems studies. Use of existing farms as study sites is less common, perhaps because the limitations are often thought to exceed the advantages. This may be due to the perception that it is extremely difficult to test hypotheses using commercial farms since many factors cannot be controlled across different farms. The use of farms in agroecesystems studies is most closely aligned with approaches used to study natural ecosystems and represents a major divergence from 
Legume-based

Corn, soybeans, small grains, leguminous green manures

$42 \mathrm{~kg} \cdot \mathrm{ha}^{-1} \mathrm{~N}$ per year, leguminous residue

Growing plants: $70 \%$; fallow w/residues: $22 \%$; bare fallow: $8 \%$

Moldboard plow, $1.3 \times$ per year

Rotary hoeing, cultivation, rotation

\section{Conventional}

Corn, soybeans

$87 \mathrm{~kg} \cdot \mathrm{ha}^{-1} \mathrm{~N}$ per year, mineral fertilizer

Growing plants: $42 \%$; fallow w/residues: $50 \%$; bare fallow: $8 \%$

Moldboard plow, $1.0 \times$ per year

Herbicides typical agricultural research approaches. In addition to the wellknown drawback of uncontrolled variability among farm sites, a major issue is the extra cost of completely characterizing these sites in terms of soils, climate, management history, surroundings and other factors that cannot be held constant. Given this significant cost, multifaceted questions must be addressed in these studies in order to compete for funding. Onfarm studies are sometimes more difficult to carry out logistically due to the lack of control over the research sites by researchers and farms are usually less accessible than experiment stations.

The most important advantage of on-farm studies is that systems under study are realistic in terms of scale, management practice and constraints faced by the farmer and therefore offer an opportunity to study intact agroecosystems. Another advantage is that selection may be used to either minimize environmental variability or to increase variation in environmental or management factors. Needelman et al. (1999) selected farms with soil textural differences in order to investigate interactions between management practices and soil texture. Furthermore, well-established farms, which are probably closer to steady-state conditions, but with differing management regimes spanning many years can be compared. Alternatively, a chronosequence of sites that have been under management schemes for varying durations can be selected in order to test hypotheses about changes over relatively long time periods (Drinkwater et al., 1995). Finally, certain agroecosystem properties influenced by landscape-scale characteristics require use of farm-scale study sites (Letourneau et al., 1996; Elias et al., 1998) as do studies of interactions between socioeconomic factors and management decisions.

A number of studies using com- mercial farms as research sites are available (Lockeretz et al., 1981; Stynes and Veitch, 1981, 1983; Reganold et al., 1993; Drinkwater et al., 1995; Franco-Vizcaino, 1997; Wander and Bollero, 1999). In one of the earliest interdisciplinary studies of commercial farms conducted in the United States, Lockeretz et al. (1981) compared organic and conventional grain production systems in the midwestern U.S. in terms of soil properties, yields, energy use, and economics. Reganold et al. (1993) compared soil physical, chemical, and biological properties as well as profitability on 16 adjacent biodynamic and conventional farms. Drinkwater et al. (1995) compared organic and conventional tomato (Lycopersicon esculentum) systems with the hypothesis that management-induced alterations in soil processes would effect crop productivity through plant-pathogen and plant-arthropod interactions and nutrient availability. Several recent on-farm studies have examined the impacts of management practices on soil quality (FrancoVizcaino, 1997; Wander and Bollero, 1999). Commercial farms are also being used as sites for studies of nutrient budgets in agroecosystems (Nguyen et al., 1995; Baijukya and de Steenhuijsen-Piters, 1998; Elias et al., 1998; Van den Bosch et al., 1998). These studies provide examples of a variety of successful experimental approaches to on-farm research and demonstrate that hypotheses can be tested using commercial farms as study sites.

\section{Conclusions}

Previous cropping systems studies have examined attributes such as yield, soil properties, energy use and economics. New information generated from descriptive agroecosystem studies has stimulated research to test specific hypotheses. As a result, many recent agrosystems studies have investigated mechanistic hypotheses in an attempt to explain how different agroecosystems function using a combination of holistic and reductionist approaches. This integration of reductionist strategies within an ecosystem context has helped further our understanding of agroecosystem function at all levels of organization. For example, a study using commercial farms as sites for a comparison of organic and conventional tomato systems found that organically managed soils had reduced levels of root disease compared to conventionally-managed soils (Workneh et al., 1993). Subsequent reductionist experiments in controlled environments determined that organically managed soils inhibited the growth of the root pathogen and pointed to potential mechanisms for disease suppression (Workneh and van Bruggen, 1994). Continued integration of systems and reductionist approaches will likely yield a more complete understanding of how to design and manage agroecosystems for optimal short- and long-term performance. Useful references for anyone who is designing a systems experiment for the first time may be found on the Internet (Denison, 1994; Denison, 1995; Denison, 2002; Michigan State Univ., 2002; North Carolina State Univ., 2001; USDA, 2001), in extension publications (Cavigelli et al., 1998; Cavigelli et al., 2000; Peterson et al., 1999), and in textbooks (Jackson, 1997; Lowrance et al., 1984).

\section{Literature cited}

Afifi, A.A. and V. Clark. 1996. Computeraided analysis. $3^{\text {rd }}$ ed.p. 455 . Chapman and Hall, New York.

Altieri, M.A. and J.W. Todd. 1981. Some influences of vegetational diversity on insect communities of Georgia soybean fields. Protection Ecol. 3:333-338.

Aref, S. and M.M. Wander. 1998. Longterm trends of corn yield and soil organic matter in different crop sequences and soil fertility treatments on the Morrow Plots. Adv Agron. 62:153-197. 
Baijukya, F.P.and B. de Steenhuijsen-Piters. 1998. Nutrient balances and their consequences in the banana-based land use systems of Bukoba district, northwest Tanzania. Agr. Ecosystems Environ. 71:147158 .

Campbell, C.A. and R.P. Zentner. 1993. Soil organic matter as influenced by crop rotations and fertilization. Soil Sci. Soc. Amer. J. 57:1034-1040.

Cavigelli, M.A., J.R. Teasdale, K.A. Nichols, C. Shuey, S. Liang, T.H. Dao, J. Radhakrishnan, and J.E. Buyer. 2000. The USDA-ARS Farming Systems Project: Developing Sustainable Agriculture Systems for the Mid-Atlantic Region. Agron. Abstr. p. 83.

Cavigelli, M.A., S.R. Deming, L.K. Probyn, and R.R. Harwood (eds.). 1998. Michigan Field Crop Ecology: Managing biological processes for productivity and environmental quality. Mich. State Univ. Bul. E2646.

Cavigelli, M.A., S.R. Deming, L. K. Probyn, and D.R. Mutch (eds.). 2000. Michigan Field Crop Pest Ecology and Management. Mich. State Univ. Bul. E-2704.

Clark, M.S., W.R. Horwath, C. Shennan, K.M. Scow, W.T. Lanini, and H. Ferris. 1999. Nitrogen, weeds and water as yieldlimiting factors in conventional, low-input, and organic tomato systems. Agr. Ecosystems Environ. 73:257-270.

Collins, H.P., R.L. Blevins, L.G. Bundy, D.R. Christenson, W.A. Dick, D.R. Huggins, and E.A. Paul. 1999. Soil carbon dynamics in corn-based agroecosystems: results from carbon-13 natural abundance. Soil Sci. Soc. Amer. J. 63:584-591.

Crossley, D.A., G.J. House, R.M. Snider, R.J. Snider, and B.E. Stinner. 1984. The positive interactions in agroecosystems. In: Agricultural ecosystems: Unifying concepts, p. 73-81. Wiley, New York.

Daroub, R., S.F.J. Pierce, and B.G. Ellis. 2000. Phosphorus fractions and fate of phosphorus-33 in soils managed under plowing and no-tillage. Soil Sci. Soc. Amer. J. 64:170-176.

David, M.B. and L.E. Gentry. 2000. Antropogenic inputs of nitrogen and phosphorus and riverine export of Illinois, USA. J. Environ. Qual. 29:494-507.

Delate, K. 2002. Using an agroecosystem approach in systems research. HortTechnology 12(3):345-354.

Denison, R.F. 1994. LTRAS-The World's Youngest 100-year Experiment. That's not fair! Part 1. The LTRAS Century. Issue 2:1-2. 14 April 2002; <http:// ltras.ucdavis.edu/doc/century2.pdf $>$

Denison, R.F. 1995. LTRAS-The World's
Youngest 100-year Experiment. That's not fair! Part 2. The LTRAS Century. Issue 3:1-3. 14 April 2002; <http://ltras. ucdavis.edu/doc/century2.pdf>

Dennison, R.F. 2002. LTRAS-“The World's Youngest 100-year Experiment". 14 April 2002; <http://agronomy.ucdavis. edu/ltras/homepage.htm>.

Drinkwater, L.E., F. Workneh, D.K. Letourneau, A.H.C. van Bruggen, and C. Shennan. 1995. Fundamental differences in organic and conventional agroecosystems in California. Ecol. Appl. 5:1098-1112.

Drinkwater, L.E., M.W. Wagoner, and M. Sarrantonio. 1998. Legume-based systems have reduced losses of nitrogen and carbon. Nature 396:262-265.

Drinkwater, L.E., R.R. Janke, and L. Longnecker. 2000. Effects of reduced tillage intensities on nitrogen dynamics and crop productivity in legume-based cropping systems. Plant Soil 227:99-113.

Drinkwater, L.E. and P. Puget. 2001 Fate of root-derived carbon in annual cropping systems. Ecol. Soc. Amer. 86 ${ }^{\text {th }}$ Annu. Mtg. Abstr. p. 274

Elias, E., S. Morse, and D.G.R. Belshaw. 1998. Nitrogen and phosphorus balances of Kindo Koisha farms in southern Ethiopia. Agr. Ecosyst. Environ. 71:93-113.

Fließbach, A., P. Mäder, and U. Niggli. 2000. Mineralization and microbial assimilation of $14 \mathrm{C}$ labeled straw in soils of organic and conventional agricultural systems. Soil Biol. Biochem. 32:1131-1139.

Franco-Vizicano, E. 1997. Comparative soil quality in maize rotations with high or low residue diversity. Biol. Fert. Soils 24:2834.

Gregorich, E.G., C.F. Drury, and J.A. Baldock. 2001. Changes in soil carbon under long-term maize in monoculture and legume-based rotation. Can. J. Soil Sci. 81:21-31.

Harris, G.H., O.B. Hesterman, E.A. Paul, S.E. Peters, and R.R. Janke. 1994. Fate of legume and fertilizer nitrogen- 15 in a longterm cropping systems experiment. Agron. J. 86(5):910-915.

Hart, R.D. 1984. Agroecosystem determinants, p. 105-1 19. In: R. Lowarance, B.R. Stinner, and G.J. House (eds.). Agricultural ecosystems: Unifying concepts. J. Wiley, New York.

Hayes, R.J. and M.H. Beare. 1997. Influence of six crop species on aggregate stability and some labile organic matter fractions. Soil Biol. Biochem. 29:1647-1653.

Jackson, L.E. (ed.). 1997. Ecology in agriculture. Academic Press, San Diego, Calif.
Janke, R.R., J. Mt. Pleasant, S.E. Peters, and M. Bohlke. 1991. Long-term, lowinput cropping systems research, p. 291317. In: J.P. Madden (ed.). Alternative agriculture. part 2. Natl. Acad. Press., Wash., D.C.

Kramer,A.W., T.A. Doane,W.R. Horwath and C. van Kessel. 2002. Short-term nitrogen-15 recovery vs long-term total soil $\mathrm{N}$ gains in conventional and alternative corpping systems. Soil Biol. Biochem. $34: 43-50$

Larson, W.E., C.E. Clapp, W.H. Pierre, and Y.B. Morachan. 1972. Effects of increasing amounts of organic residues on continuous corn: II. Organic carbon, nitrogen, phosphorus, and sulfur. Agron. J. 64:204-208.

Lechowicz, M.J. and G.R. Shaver. 1982. A multifactor approach to the analysis of factorial fertilization experiments in Alaskan arctic tundra. Ecology 63:1029-1038.

Letourneau, D.K. 1997. Plant-arthropod interactions in agroecosystems, p. 239291. In: L.E. Jackson (ed.). Ecology in agriculture. Academic Press. San Diego, Calif.

Letourneau, D.K., L.E. Drinkwater, and C. Shennan. 1996. Soil management effects on crop quality and insect damage in commercial organic and conventional tomato fields. Agr. Ecosyst. Environ. 57:179187.

Liebhardt, W.C., R.W. Andrews, M.N. Culik, R.R. Harwood, R.R. Janke, J.K. Radke, and S.L. Rieger-Schwartz. 1989. Crop production during conversion from conventional tolow-input methods. Agron. J. 81(2):150-159.

Liebman, M. and E. Dyck. 1993. Crop rotation and intercropping strategies for weed management. Ecol. Appl. 3:92-122.

Little, T.M. and F.J. Hills. 1978. Agricultural Experimentation: Design and Analysis. Wiley and Sons, NY. 350 pp.

Lowrance, R, B.R. Stinner, and G.J. House (eds). 1984. Agricultural ecosystems: Unifying concepts. Wiley, New York.

Lockeretz, W., G. Shearer, and D.H. Kohl. 1981. Organic farming in the corn belt. Science 211:540-546.

Lundquist, E.J., L.E. Jackson, K.M. Scow, and C. Hsu. 1999. Changes in microbial biomass and community composition, and soil carbon and nitrogen pools after incorporation of rye into three California agricultural soils. Soil Biol. Biochem. 3l(2):221-236.

Marino, P.C. and D.A. Landis. 1996. Effect of landscape structure on parasitioid diversity and parasitism in agroecosystems. Ecol. Appl. 6:276-284. 
Meisinger, J.J., V.A. Bandel, G. Stanford, and J.O. Legg. 1985. Nitrogen utilization of corn under minimal tillage and moldboard plow tillage. I. Four-year results using labeled $\mathrm{N}$ fertilizer on an Atlantic coastal plain soil. Agron. J. 77:602-611.

Michigan State University. 2002. The KBS LTER Site: Long-Term Ecological Research in Row-Crop Agriculture. 14 Apr. 2002 <http://lter.kbs.msu.edu/>

Mueller, J.P., M.E. Barbercheck, M. Bell, C. Brownie, N.G. Creamer, S. Hu, L. Kin, H.M. Linker, F.J. Louws, M. Marra, J.P. Mueller, C.W. Raczkowski, D. Susko, and M.G. Wagger. 2002. Implementation of long-term agricultural systems studies: Challenges and opportunities. HortTechnology 12(3):362-368.

Needelman, B.A., M.M. Wander, G.A. Bollero, C.W. Boast, G.K. Sims, and D.G. Bullock. 1999. Interaction of tillage and soil texture: Biologically active soil organic matter in Illinois. Soil Sci. Soc. Amer. J. 63:1326-1334.

Nguyen, M.L., R.J. Haynes, and K.M. Goh. 1995. Nutrient budgets and status in three pairs of conventional and alternative mixed cropping farms in Canterbury, New Zealand. Agr. Ecosyst. Environ. 52:149162.

North Carolina State University. 2001. Center for Environmental Farming Systems: Farming Systems Unit. 14 Apr. 2002. <http://www.cals.ncsu.edu/ sustainable_ag/Units.htm>

Peters, S., R. Janke, and M. Bohlke. 1992. Rodale's farming systems trial 1986-1990. Rodale Press, Emmaus, Pa.

Peters, S.E., M.M. Wander, L.S. Saporito, G.H. Harris, and D.B. Friedman. 1997. Management impacts on SOM and related soil properties in a long-term farming systems trial in Pennsylvania: 1981-1991, p. 193-196. In: E.A. Paul, K. Paustian, E.T. Elliott, and C.V. Cole (eds.). Soil organic matter in temperate agroecosystems: Longterm experiments in North America. CRC Press, Boca Raton, Fla.

Peterson, C., L.E. Drinkwater and P. Wagoner. 1999. The Farming Systems Trial: The first fifteen years. Rodale Inst., Kutztown, Pa.

Phelan, P.L., J.F. Mason, and B.R. Stinner. 1995. Soil-fertility management and host preference by European corn borer, Ostrinia nubilalis(Huebner), on Zea mays L.: A comparison of organic and conven- tional chemical farming. Agr. Ecosyst. Environ. 56 (1):1-8.

Posner, J.L., M.D. Casler, and J.O. Baldock. 1995. The Wisconsin integrated cropping systems trial: Combining agroecology with production agronomy. Amer. J. Alt. Agr. 10:98-10.

Poudel, D.D., W.R. Horwath, J.P. Mitchell, and S.R. Temple. 2001. Impacts of cropping systems on soil nitrogen storage and loss. Agr. Syst. 68:253-268.

Puget, P. and L.E. Drinkwater. 2001. Short-term dynamics of root and shootderived carbon from a leguminous green manure. Soil Sci. Soc. Amer. J. 65:771779 .

Reganold, J.P., A.S. Palmer, J.C. Lockhart, and A.N. Macgregor. 1993. Soil quality and financial performance of biodynamic and conventional farms in New Zealand. Science 260:344-349.

Reganold, J.P., J.D. Glover, P.K. Andrews, and H.R. Hinman. 2001. Sustainability of three apple production systems. Nature 410:926-930.

Reider, C., W. Herdman, L.E. Drinkwater, and R. Janke. 2000. Yields and nutrient budgets under composts, raw dairy manure and mineral fertilizer. Compost Sci. Utilization 8:328-339.

Robertson, G.P., E.A. Paul, and R.R. Harwood. 2000. Greenhouse gases in intensive agriculture: Contributions of individual gases to the radiative forcing of the atmosphere. Science 289:1922-1925.

Ryszkowski, L., J. Karg, G. Margalit, M.G. Paoletti, and R. Zoltin. 1993. Aboveground insect biomass in agricultural landscapes of Europe, p. 71-82. In: R.G.H. Bunce, L. Ryszkowski, and M.G. Paoletti (eds.). Landscape ecology and agroecosystems. Lewis, Ann Arbor, Michigan.

Scow, K.M., O. Somasco, N. Gunapala, S. Lau, R. Venette, H. Ferris, R. Miller, and C. Shennan. 1994. Transition from conventional to low-input agriculture changes soil fertility and biology. Calif. Agr. 48:20 26.

Shennan, C., L.E. Drinkwater, A.H.C. van Bruggen, D.K. Letourneau, and F. Workneh. 1991. Comparative study of organic and conventional tomato production systems: an approach to on-farm research, p. 109-132. In: J.P. Madden (ed.). Alternative agriculture. part 2. Natl. Acad. Press, Wash., D.C.
Stynes, B.A. and L.G. Veitch. 1981. A synoptic approach for crop loss assessment used to study wheat. IV. The description of cultural practices and the combination of cultural data with soil data. Austral. J. Agr. Res. 32:1-8.

Stynes, B.A. and L.G. Veitch. 1983. A synoptic approach for crop loss assessment used to study wheat. VI. The pathogen data and their relationship to soil and cultural practice data. Austral. J. Agr. Res. 34:167-181.

Temple, S.R., D.B. Friedman, O. Somasco, H. Ferris, K.M. Scow, and K. Klonsky. 1994. An interdisciplinary, experiment station-based participatory comparison of alternative crop management systems for California's Sacramento valley. Amer. J. Alt. Agr. 9:64-71.

U.S. Department of Agriculture. 2001. Development of sustainable and organic farming systems and management practices (in the Mid-Atlantic region). 14 April 2002. <http://www.nps.ars.usda.gov/ projects $/$ projects.htm?accession $=402192>$

van den Bosch, H., J.N. Gitari, V.N. Ogaro, S. Maobe, and J. Vlaming. 1998. Monitoring nutrient flows and economic performance in African farming systems (NUTMON). III. Monitoring nutrient flows and balances in three districts in Kenya. Agr. Ecosyst. Environ. 71:63-80.

Wander, M.M, S.J. Traina, R.B. Stinner, and S.E. Peters. 1994. The Effects of organic and conventional management on biologically active soil organic matter pools. Soil Sci. Soc. Amer. J. 58:1130-1139.

Wander, M.M. and G.A. Bollero. 1999. Soil quality assessment in Illinois. Soil Sci. Soc. Amer. J. 63:961-971.

Workneh, F. and A.H.C. van Bruggen. 1994. Suppression of corky root of tomatoes in soil from organic farms associated with soil microbial activity and nitrogen status of soil and tomato tissue. Phytopathology 84:688-694.

Workneh, F., A.H.C. van Bruggen, L.E. Drinkwater, and C. Shennan. 1993. Relationships between soil variables and corky root and phytophthora root rot of tomatoes in organic and conventional farms. Phytopathology 83:581-580. 